\title{
MJN RISK FACTORS OF TRANSMISSION OF CORONAVIRUS DISEASE 2019 (COVID-19) IN CHILDREN: A REVIEW
}

\author{
Ninin Herlinawati ${ }^{1}$, Yulis Setiya Dewi ${ }^{1 *}$, llya Krisnana ${ }^{1}$, Yoyok Bekti Prasetyo ${ }^{2}$, Amel Dawood Kamel ${ }^{3,4}$ \\ ${ }^{1}$ Faculty of Nursing, Universitas Airlangga, Surabaya Indonesia \\ ${ }^{2}$ Faculty Health Sciences, University Muhammadiyah of Malang Indonesia \\ ${ }^{3}$ College of Nursing, King Saud Bin Abdulaziz University for health sciences Riyadh-national guard, KSA \\ ${ }^{4}$ Department of Maternal and Newborn Health Nursing, Faculty of Nursing, Cairo University, Egypt \\ *Corresponding Author's Email: yulis.sd@fkp.unair.ac.id
}

\begin{abstract}
Introduction: The transmission of Coronavirus Disease 2019 (COVID-19) in children in the world is still high, especially from the environment where children live and play. The purpose of this review was to analyze host and environmental factors for the risk of transmission of COVID-19 in children, based on empirical studies in the last 2 years. Methods: Search for journals or articles were used databases including Scopus, Science Direct, Proquest and Pubmed. Journal search was conducted from April to October 2020. The PRISMA checklist was used to assess study feasibility. The framework used to review is PICOS and the inclusion criteria used are English-language journals published in 2019 to 2020, discussions related to transmission to children, and the population is children. The data collection was carried out by examining the title, abstract, full text and assessed methodology to determine the eligibility of the journal. Results: Thirty hundred journals have been identified, there are twelve journals that match the research criteria, the study explains the risk factors for the transmission of coronavirus disease 2019 (COVID-19) in children ( $\mathrm{n}=12$ ). Research designs that are widely used to discuss factors associated with the transmission of COVID-19 in children are the Cohort studies, Case-report studies, Case Control, Survey studies, Observes Studies dan Mix method Discussion: Host factors that influence the incidence of COVID-19 in children are immunity, comorbidities, personal hygiene behavior and nutritional status. Children with low immunity and comorbid susceptibility to contracting the virus and will become severe when the child's nutritional status is poor. Conclusion: The environmental factor of the child tends to be transmitted in the child's home and play environment. It is necessary to implement health protocols and increase nutritional intake especially for children.
\end{abstract}

Keywords: Risk Factors; Infection; COVID-19; Transmission; Children

\section{INTRODUCTION}

The transmission of Coronavirus Disease 2019 (COVID-19) in children in the world is still high with a number of 179,990 (De Luca et al., 2020). Transmission that occurs to children comes from adults who are career or virus carriers or parents who are positive without symptoms so they do not realize that they have the potential to infect their family and other people who live in the same house (Kobayashi et al., 2020). This happens because of the interaction between parents and children while at home (Wang et al., 2020). The spread of the virus, which is basically through droplets, will occur very quickly with the presence of hugs, kissing children and the habits of parents who ignore the correct cough etiquette (Duff, 2020). Child immunity factors influence the incidence of transmission in children. The impact felt by a child infected with COVID-19 will be seen after a few days of exposure, starting from no symptoms to death. From a child's perspective, there are also many factors that cause transmission or cross infection to occur very quickly from adult to child or 
from one child to another. So that in general, the factor of COVID-19 transmission in children cannot be known.

Reporting from April to October 2020 the number of positive cases of COVID-19 in the world reached $3,139,690$ cases, with a monthly average of 381 thousand cases (Manderson \& Levine, 2020). According to (Wu et al., 2020) the incidence of COVID19 in children aged $10-19$ years was $549 / 72,314$ or $1 \%$ of all cases, while the age group $<10$ years was 416 / 72,314 or $0.9 \%$ of cases. According to data from the Task Force for the Acceleration of Handling of COVID19, more than 2712 children infected with COVID-19 and 51 of them (who were under 18 years old) died from the corona virus, and most of them were toddlers. This is equivalent to $1.7 \%$ of total deaths due to COVID-19 with comorbidity of asthma, leukemia, congenital heart defects, and meningitis, which according to the Indonesian Pediatric Association, was one of the highest in Asia and the world.

The number of COVID-19 cases in children is influenced by outside environment where they stayed. Transmission that occurs due to parental negligence in supervising children and parental awareness in taking care of themselves is still lacking (Zar et al., 2020). The rapid and radical transmission of this virus is influenced by environmental factors, immunity conditions and the nature of the virus itself (Ying et al., 2020). In general, the factors that influence the transmission of COVID-19 are environmental conditions, the host, namely the human, and the agent, namely the virus. So that serious attention is needed related to transmission to prevent sustainable transmission because the impact is very large, such as insufficient health facilities and health workers to accommodate and provide care for patients who are positive for COVID-19 (Ying et al., 2020).

The impact of the infection process on the development of children have longer effect. Children under six years can interfere with basic growth and development, namely motor skills, language speaking skills, and the ability of independent personnel. Meanwhile, in children aged six years, the infection process at an early age can interfere with their growth and development in terms of behavior and intelligence. John Gordon's theory states that the emergence of a disease is strongly influenced by three factors, namely germs Agent), host (Host), and environment (Alligood, \& Tomey, (2014)). The agent factor that is of course clear is the COVID-19 virus, then the host factor is the child which is influenced by the child's habits with the child's health protocol and the child's immune system and environmental factors are the home where the child gathers with other adults including parents who may be sufferers of COVID-19. Therefore it is necessary to conduct a study that summarizes the transmission of COVID-19 to determine the factors that affect transmission in children.

\section{METHODOLOGY}

\section{Search Strategy}

The authors have performed a systematic primary search of the literature that resulted in a used keywords in this "literature review" are adjusted to "Medical Subject Heading (MeSH)." The keywords in this literature search are "Factor" OR "Risk Factore" OR "Causes" AND "Infection" OR "Transmission" OR "Contact (Behavior)" AND "Covid-19" OR "SARS COV-2" OR "Coronavirus" AND "Pediatric" OR "Children" OR "Child". The authors have searched for articles using an electronic literature search of Scopus, Science Direct, Proquest and Pubmed databases published during the period from 2019 to 2020. We have used the Ten articles which met the inclusion criteria were selected from the search as shown in (Figure 1). The studies have been summarized as shown in (Table 1).

\section{Review Process}

Two of the investigators initially reviewed article titles for relevance to include in this review paper. These studies were screened to remove duplicate studies by entering them into a computer-based referred management system. The abstracts were screened for the inclusion criteria by the two investigators. Inclusion criteria were (1) limited to english language studies; (2) 0-18 years participants; (3) one of the main outcome variables measured was risk factors or predictors of transmission of covid-19 to children; (4) original primary research article published in a peer-reviewed journal; and (5) article published between the years 2019 to 2020. On the basis of screening, the full text article was obtained for the second stage screening. Researcher performed the second stage screening and downloaded 330 references. The title and abstracts were screened for relevance and identified 136 articles. Using the inclusion criteria, 12 articles were identified from these 330 articles. The process, of handling the retrieved articles are outlined as in Figure 1. 


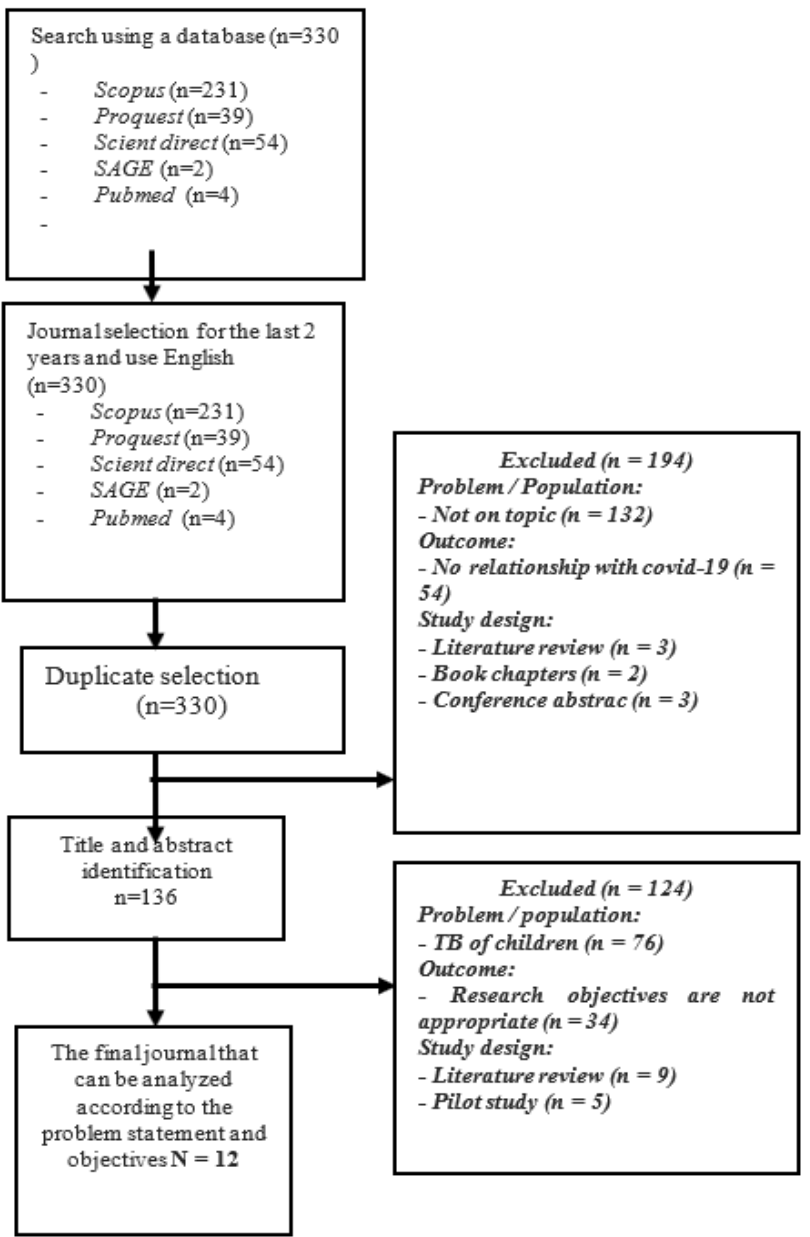

Figure 1: Diagram Flow for Relevant Articles Finding

\section{Analysis and assessment of study quality}

The findings were presented in a narrative format; the 12 articles that met the inclusion criteria used different methodology and instruments (method heterogeneity) to measure the outcome variables risk factors or predictors of covid-19 transmission. For this reason, it was not possible to use meta-analysis process to generate a sound quantifiable conclusion. The results were presented in a tabular format (Table 1). We assessed the following aspects of the study quality: (1) study design and variable (2) sampling (3) data collection instruments.

\section{RESULTS}

This literature review study uses twelve international journals that have passed screening according to inclusion and exclusion criteria. Overall, the twelve journals describe the risk factors for the transmission of coronavirus disease 2019 (COVID-19) in children, the twelve journals can be seen in (Table 1). The studies that the authors found that fit the topic were conducted in China, namely three studies (Liu et al., 2020; Dong et al., 2020; Zhou et al., 2020), two studies in Italy (Götzinger et al., 2020: Bellino et al., 2020), and one study each in America (Wilke et al., 2020), in Vietnam Le et al., 2020), in Bangladesh (Hamadani et al., 2020), in India (Saha \& Chouhan, 2020), in Taiwan (Cao et al., 2020), in France (Hubiche et al., 2020), in Australia (Ibrahim et al., 2020). The results of the study search found by the author can be seen in table 1 .

Table 1: The Results of the Study Search Found by the Author

\begin{tabular}{|c|c|c|c|c|c|}
\hline No & \begin{tabular}{|c|} 
Author, year, vol, \\
and country
\end{tabular} & Publisher & Title & Method & Rsults of Research \\
\hline 1 & $\begin{array}{l}\text { Bellino et al } \\
2020, \\
\text { Vol:146 } \\
\text { Issue:4 } \\
\text { ISSN: } \\
\text { 10984275 } \\
\text { Italy }\end{array}$ & $\begin{array}{l}\text { America } \\
\text { Academic of } \\
\text { Pediatrics }\end{array}$ & $\begin{array}{l}\text { COVID-19 Disease } \\
\text { Severity Risk Factors } \\
\text { for Pediatric Patients } \\
\text { in Italy }\end{array}$ & $\begin{array}{l}\text { Design: Case Report } \\
\text { Sample: } 3,836 \\
\text { children in Italy } \\
\text { Variables: age, } \\
\text { comorbid, social } \\
\text { contact, COVID-19 } \\
\text { Instruments: } \\
\text { Secondary data, PCR } \\
\text { swab test } \\
\text { Analysis: Regression }\end{array}$ & $\begin{array}{l}\text { The risk factors for transmitting } \\
\text { COVID-19 to children are age, } \\
\text { comorbidities and close contact } \\
\text { with positive people and the } \\
\text { environment. }\end{array}$ \\
\hline 2 & \begin{tabular}{l|} 
Ibrahim et al., \\
2020, \\
Vol: 32 \\
Issue:5 \\
Pages:801- \\
808 \\
ISSN:17426723 \\
Australia
\end{tabular} & $\begin{array}{l}\text { EMA - } \\
\text { Emergency } \\
\text { Medicine } \\
\text { Australasia }\end{array}$ & $\begin{array}{l}\text { SARS-CoV-2 testing } \\
\text { and outcomes in the } \\
\text { first } 30 \text { days } \\
\text { after the first case of } \\
\text { COVID-19 at an } \\
\text { Australian } \\
\text { children's hospital }\end{array}$ & $\begin{array}{l}\text { Design: Cohort study } \\
\text { Sample: } 433 \text { patients } \\
\text { Variable: Comor bid, } \\
\text { COVID-19 } \\
\text { Instrument: Secondary } \\
\text { data from PCR lab } \\
\text { results } \\
\text { Statistic analysis }\end{array}$ & $\begin{array}{l}\text { The risk factors for transmission } \\
\text { to children are comorbids, } \\
\text { asthma }\end{array}$ \\
\hline
\end{tabular}




\begin{tabular}{|c|c|c|c|c|c|}
\hline 3 & $\begin{array}{l}\text { Le et al } \\
2020, \\
\text { Vol:4 } \\
\text { Issue:5 } \\
\text { Pages: } 405 \text { - } \\
406 \\
\text { ISSN:2352- } \\
4642 \\
\\
\text { Vietnam }\end{array}$ & $\begin{array}{l}\text { The Lancet } \\
\text { Child \& } \\
\text { Adolescent } \\
\text { Health }\end{array}$ & $\begin{array}{l}\text { The first infant case of } \\
\text { COVID-19 acquired } \\
\text { from a secondary } \\
\text { transmission in } \\
\text { Vietnam }\end{array}$ & $\begin{array}{l}\text { Design: Case report } \\
\text { Sample: } 1 \text { baby case } \\
\text { who tested positive for } \\
\text { COVID-19 in } \\
\text { Vietnam. } \\
\text { Variables: Close } \\
\text { contact, family, } \\
\text { pregnant women, } \\
\text { COVID-19 } \\
\text { Instruments: } \\
\text { Secondary data } \\
\text { Analysis: Distribution } \\
\text { analysis }\end{array}$ & $\begin{array}{l}\text { Risk factors for transmission of } \\
\text { COVID-19 to children include } \\
\text { pregnant women to their babies, } \\
\text { contact with family members } \\
\text { who are positive for COVID-19, } \\
\text { close contact }\end{array}$ \\
\hline 4 & $\begin{array}{l}\text { Hamadani et } \\
\text { al, } \\
2020 \text {, } \\
\text { Vol: } 8 \\
\text { Issue:11 } \\
\text { Pages:e1380- } \\
\text { e1389 } \\
\text { ISSN: } \\
\text { 20937997 } \\
\text { Bangladesh }\end{array}$ & $\begin{array}{l}\text { The Lancet } \\
\text { Child \& } \\
\text { Adolescent } \\
\text { Health }\end{array}$ & $\begin{array}{l}\text { Immediate impact of } \\
\text { stay-at-home orders to } \\
\text { control COVID -19 } \\
\text { transmission on } \\
\text { socioeconomic } \\
\text { conditions, food } \\
\text { insecurity, mental } \\
\text { health, and intimate } \\
\text { partner vio lence in } \\
\text { Bangladeshi women } \\
\text { and their families: an } \\
\text { interrupted time series }\end{array}$ & $\begin{array}{l}\text { Design: Case Control } \\
\text { Sample: } 2424 \text { mothers } \\
\text { of children in } \\
\text { Bangladesh } \\
\text { Variables: social and } \\
\text { economic status, } \\
\text { nutrition, COVID-19 } \\
\text { Instruments: } \\
\text { Questionnaires and } \\
\text { secondary data } \\
\text { Analysis: Regression }\end{array}$ & $\begin{array}{l}\text { The risk factors for transmitting } \\
\text { COVID-19 to children are low } \\
\text { socioeconomic status and } \\
\text { nutritional status. }\end{array}$ \\
\hline 5 & $\begin{array}{l}\text { Wilke, Hiles, } \\
\text { \& Goldman } \\
2020, \\
\text { Vol: } 110 \\
\text { Issue:P2 } \\
\text { Pages: } \\
\text { 104712 } \\
\text { ISSN:187377 } \\
57 \\
\text { America }\end{array}$ & $\begin{array}{l}\text { Child Abuse \& } \\
\text { Neglect }\end{array}$ & $\begin{array}{l}\text { Rapid return of } \\
\text { children in residential } \\
\text { care to family as a } \\
\text { result of COVID-19: } \\
\text { Scope, challenges, and } \\
\text { recommendations }\end{array}$ & $\begin{array}{l}\text { Design: Mix method } \\
\text { Sample: } 75,483 \\
\text { children in } 14 \\
\text { countries in America } \\
\text { Variables: income, } \\
\text { Comorbid, cleanliness, } \\
\text { PPE } \\
\text { Instrument: Online } \\
\text { survey } \\
\text { Analysis: Regression }\end{array}$ & $\begin{array}{l}\text { Risk factors for transmission of } \\
\text { COVID-19 to children with low } \\
\text { or middle income families, } \\
\text { unable to maintain distance and } \\
\text { hand hygiene, lack of PPE and } \\
\text { comorbidities. }\end{array}$ \\
\hline 6 & $\begin{array}{l}\text { Götzinger et } \\
\text { al., } \\
2020, \\
\text { Vol:4642 } \\
\text { Issue:20 } \\
\text { Pages:1-9 } \\
\text { ISSN:153765 } \\
91 \\
\text { Italy }\end{array}$ & $\begin{array}{l}\text { Lancet Child } \\
\text { Adolesc Health } \\
2020\end{array}$ & $\begin{array}{l}\text { COVID-19 in children } \\
\text { and adolescents in } \\
\text { Europe: a } \\
\text { multinational, } \\
\text { multicentre cohort } \\
\text { study }\end{array}$ & $\begin{array}{l}\text { Design: Multicenter } \\
\text { Cohort Study } \\
\text { Sample: } 582 \text { children } \\
\text { who tested positive for } \\
\text { COVID-19. } \\
\text { Variables: age under } 5 \\
\text { years, comorbid, } \\
\text { immunity, COVID-19. } \\
\text { Instrument: Online } \\
\text { questionnaire } \\
\text { Analysis: Mann- } \\
\text { Whitney and Fisher }\end{array}$ & $\begin{array}{l}\text { The risk factors for transmission } \\
\text { are children under } 5 \text { years of } \\
\text { age, comorbid or pre-existing } \\
\text { medical conditions and the } \\
\text { child's immunity. }\end{array}$ \\
\hline 7 & $\begin{array}{l}\text { Saha \& } \\
\text { Chouhan, } \\
2020, \\
\text { Vol: } 266 \\
\text { Pages:115250 } \\
\text { ISSN: 0269- } \\
7491 \\
\text { India }\end{array}$ & $\begin{array}{l}\text { Environmental } \\
\text { pollution }\end{array}$ & $\begin{array}{l}\text { Indoor air pollution } \\
\text { (IAP) and pre -existing } \\
\text { morbidities among } \\
\text { under-5 } \\
\text { children in India: are } \\
\text { risk factors of } \\
\text { coronavirus disease } \\
\text { (COVID-19)? }\end{array}$ & $\begin{array}{l}\text { Design: Study / } \\
\text { Prevalance Survey } \\
\text { Sample: } 247,743 \\
\text { children under five in } \\
\text { India Variable: Air } \\
\text { pollution, comorbid, } \\
\text { environment / red } \\
\text { zone, COVID-19. } \\
\text { Instrument: Survey } \\
\text { Analysis: Spearman } \\
\text { Statistics }\end{array}$ & $\begin{array}{l}\text { Risk factors for transmission of } \\
\text { COVID-19 are caused by air } \\
\text { pollution or air contaminated } \\
\text { with the COVOD - } 19 \text { virus, the } \\
\text { environment or being in the red } \\
\text { zone. }\end{array}$ \\
\hline
\end{tabular}




\begin{tabular}{|c|c|c|c|c|c|}
\hline 8 & $\begin{array}{l}\text { T. Liu et al., } \\
2020 \text {, } \\
\text { Vol: } 9 \\
\text { Issue: } 1 \\
\text { China }\end{array}$ & $\begin{array}{l}\text { Emerging } \\
\text { Microbes \& } \\
\text { Infections }\end{array}$ & $\begin{array}{l}\text { Risk factors associated } \\
\text { with COVID -19 } \\
\text { infection: a } \\
\text { retrospective cohort } \\
\text { study based on } \\
\text { contacts tracing }\end{array}$ & $\begin{array}{l}\text { Design: Retrospective } \\
\text { Cohort Study } \\
\text { Sample: } 515 \text { positive } \\
\text { children for COVID- } \\
19 \text { in Guandhong. } \\
\text { Variables: family, } \\
\text { close family, close } \\
\text { contact, COVID-19 } \\
\text { Instruments: } \\
\text { Secondary data } \\
\text { Analysis: Logistic } \\
\text { regression and Chi } \\
\text { square test }\end{array}$ & $\begin{array}{l}\text { The risk factors for transmission } \\
\text { to children are non -compliance } \\
\text { with health protocols and the } \\
\text { presence of a family member } \\
\text { who has close contact with a } \\
\text { family member who is positive } \\
\text { for COVID-19. }\end{array}$ \\
\hline 9 & $\begin{array}{l}\text { Dong et al., } \\
\text { 2020, } \\
\text { Vol: } 22 \\
\text { Issue: } 2 \\
\text { China }\end{array}$ & $\begin{array}{l}\text { American } \\
\text { Academy of } \\
\text { Pediatrics }\end{array}$ & $\begin{array}{l}\text { Epidemiological } \\
\text { Characteristics of } \\
2143 \text { Pediatric } \\
\text { Patients With } 2019 \\
\text { Coronavirus Disease } \\
\text { in China }\end{array}$ & $\begin{array}{l}\text { Design: Case Report } \\
\text { Sample: } 2,143 \\
\text { children who tested } \\
\text { positive for COVID- } \\
19 \\
\text { Variables: Age, close } \\
\text { contact, Infection Sars } \\
\text { Cov-2 } \\
\text { Instruments: } \\
\text { Secondary data } \\
\text { Analysis: Chi-square } \\
\text { test, Fisher exact test } \\
\text { and the Mann-Whitney } \\
\text { test }\end{array}$ & $\begin{array}{l}\text { Transmission that occurs in } \\
\text { children under } 7 \text { years of age, } \\
\text { male sex, interaction between } \\
\text { parents and children at close } \\
\text { range and touching the child's } \\
\text { face area }\end{array}$ \\
\hline 10 & $\begin{array}{l}\text { Cao et al., } \\
2020, \text { Vol:119 } \\
\text { Issue:3 } \\
\text { Pages:670- } \\
673 \\
\text { ISSN:187608 } \\
21 \\
\text { Taiwan }\end{array}$ & $\begin{array}{l}\text { pediatric } \\
\text { perspective }\end{array}$ & $\begin{array}{l}\text { SARS-CoV-2 infection } \\
\text { in children: } \\
\text { Transmission } \\
\text { dynamics and clinical } \\
\text { characteristics }\end{array}$ & $\begin{array}{l}\text { Design: Cohort study } \\
\text { / Perspective study } \\
\text { Sample: } 398 \text { children } \\
\text { with COVID-19 } \\
\text { Variables: Family } \\
\text { cluster, toys / objects, } \\
\text { Infection Sars Cov-2. } \\
\text { Instrument: Checklist } \\
\text { sheet } \\
\text { Statistic analysis }\end{array}$ & $\begin{array}{l}\text { Transmission to children occurs } \\
\text { in the school environment, } \\
\text { contact with family members } \\
\text { and contaminated toys / objects. }\end{array}$ \\
\hline 11 & $\begin{array}{l}\text { Zhou et al., } \\
2020, \\
\text { Vol:96 } \\
\text { Pages: } 710 \text { - } \\
714 \\
\text { ISSN: } \\
\text { 1201-9712 } \\
\text { China }\end{array}$ & $\begin{array}{l}\text { Pediatric } \\
\text { infection } \\
\text { journal }\end{array}$ & $\begin{array}{l}\text { From SARS to } \\
\text { COVID-19: What we } \\
\text { have learned about } \\
\text { children infected with } \\
\text { COVID-19 }\end{array}$ & $\begin{array}{l}\text { Design: Cohort study } \\
\text { Sample: } 3 \text { newborns } \\
\text { in China who tested } \\
\text { positive for COVID- } \\
19 \\
\text { Variables: newborn, } \\
\text { family member, close } \\
\text { contact, COVID-19 } \\
\text { Instrument: Checklist } \\
\text { sheet } \\
\text { Statistic analysis }\end{array}$ & $\begin{array}{l}\text { The risk factor for transmitting } \\
\text { COVID-19 to a child is a } \\
\text { newborn of a positive mother } \\
\text { with COVID -19, close contact } \\
\text { with positive family members. } \\
\text { and are infected by children } \\
\text { outside the home, such as } \\
\text { schools and playgrounds }\end{array}$ \\
\hline 12 & $\begin{array}{l}\text { T Hubiche et } \\
\text { al, } \\
2020, \\
\text { Vol:16 } \\
\text { Pages:1-22 } \\
\text { ISSN: } 0151 \text { - } \\
9638 \\
\text { France }\end{array}$ & $\begin{array}{l}\text { Annales de } \\
\text { dermatologie et } \\
\text { de venereologie }\end{array}$ & $\begin{array}{l}\text { Acute acral eruptions } \\
\text { in children during the } \\
\text { COVID-19 pandemic: } \\
\text { characteristics of } 103 \\
\text { children and their } \\
\text { family cluster }\end{array}$ & $\begin{array}{l}\text { Design: Multicentre } \\
\text { observational study } \\
\text { Sample: } 103 \text { children } \\
\text { in France Variable: } \\
\text { family member, close } \\
\text { contact, COVID-19 } \\
\text { Instruments: } \\
\text { Secondary data } \\
\text { Analysis: Wilcoxon }\end{array}$ & $\begin{array}{l}\text { The risk factor for a child } \\
\text { contracting COVID - } 19 \text { is close } \\
\text { contact with a family member } \\
\text { who is positive for COVID- } 19 \text {. }\end{array}$ \\
\hline
\end{tabular}


The articles or journals to be reviewed include the database used, the year of publication, and the research design. Overall, the twelve journals describe the risk factors for transmitting COVID-19 to children. The research design that is widely used to discuss factors associated with the transmission of COVID-19 to children is the Cohort Study. namely as many as 5 articles or $42 \%$. Characteristics of children who are respondents in this literature review are based on age, illustrating that seen from the entire sample, the dominant age of the respondents is that of children under 5 years of age, namely 247,743 respondents or $74.24 \%$. The rest of the respondents were children under 18 years old and babies less than 1 year old. The factors of transmission of COVID-19 in children are divided into 2 (two) major themes, namely host factors and environmental factors. The environmental factor found by the authors based on the study results is the factor of close contact with family members or adults, or playmates who are positive for COVID-19 who without realizing they have been infected with COVID-19 (Bellino et al., 2020; Liu et al., 2020; Dong et al., 2021; Hubiche et al., 2020). Another environmental factor is that children can be infected with COVID-19 from a school environment, play environment or toys contaminated with the virus (Cao, et al., 2020; Hamadani et al., 2020). Host factors or factors from children, namely immunity and the presence of comorbids such as asthma and other chronic diseases according to the study (Ibrahim et al., 2020; Götzinger et al., 2020; Wilke et al., 2020) besides hygiene factors or not adhering to health protocols such as not being able to maintain hand hygiene (Wilke et al., 2020; Liu et al., 2020) Socio-economic factors and income of household heads that affect the ability to provide resources such as limited nutritional food intake, availability of masks, availability of tools for hand hygiene, space for independent isolation / keeping a distance, houses are narrow and there is no air ventilation (Hamadani et al., 2020; Wilke et al., 2020; Saha \& Chouhan, 2020). Factors for babies infected with COVID-19 who were acquired while in the womb, were born to mothers who were positive for COVID-19, or transmission could occur during the interaction between breastfeeding and kissing the baby (Le et al., 2020; Dong et al., 2021; Zhou etal., 2020).

\section{DISCUSSION}

\section{Host Factor of Children}

\section{Imunity Factor}

Based on the results of the review of the articles conducted by the researcher, it was found in the study (Götzinger et al., 2020) shows a relationship between transmission and immunity status of children. The body's immune system has a function, namely to help repair human DNA, prevent infections caused by fungi, bacteria, viruses, and other organisms, and produce antibodies (a type of protein called immunoglobulin) to combat invasion of foreign bacteria and viruses into the body. The job of the immune system is to find and destroy invaders that harm the human body.

Children with low immunity will easily catch COVID-19 because the body's defenses are not good. Infection that occurs in children will often cause symptoms that vary from mild to severe according to the child's body response (Sun, Chen, \& Viboud, 2020). Children become susceptible to infection due to the absence of antibodies or immunity to SARS-Cov2 and changes in the susceptibility of the host response to the agent, and / or factors that increase exposure (Adhikari et al., 2020). Children can be taught to exercise regularly and maintain body fitness to increase endurance and maintain it so that the body is not susceptible to disease. Resistance to disease depends on the quality of the immune system if it is in optimal condition it will avoid disease whereas if it decreases it will be susceptible to disease (Yuliarto, 2013). Based on the results of the study, the authors state that immunity in children, especially toddlers, has not been well developed so that younger children have weak immunity status, this can be a risk factor for children who are very susceptible to contracting COVID-19 from adults.

\section{Factors of Non-Compliance with Health Protocols}

Based on the results of the review of the article, it was stated that the host factors stated in the study were mostly related to non-compliance with health protocols such as poor hand hygiene. The results of these studies are shown by (Götzinger et al., 2020; Wilke et al., 2020). Hands are part of the body that is susceptible to dirt and germs attached. When holding something, touching, cleaning vital organs after or before defecating or urinating and shaking hands, such activities can cause germs to stick to the skin of the hands and enter orally by mouth because of the lack of cleanliness in washing hands with germs that are infected. still attached to the hand (Dong et al., 2021). Apart from hand hygiene, parents are also not obedient to using masks, not wearing masks at home even if they 
are coughing or sick (Wilke et al., 2020). The behavior of covering the nose and mouth must also be accustomed to children, such as using masks according to standards. Children often touch anything then rub their nose and eat without washing their hands or other facial areas, allowing the virus to enter the body through these areas (Dong et al., 2020) From the results of the study, it can be stated that children have a tendency not to wash their hands after holding objects or toys around them and then do activities to eat or touch their playmates and toys around them. This results in transmission between friends.

\section{Comorbid Factor}

Several articles reviewed stated that, comorbids also have an effect on the transmission of COVID-19, in research by (Ibrahim et al., 2020; Wilke et al., 2020; Götzinger et al., 2020) shows that comorbid is one of the causes of high transmission in children. This is confirmed by the research of (Ludvigsson, 2020) which shows that comorbids are a factor affecting the transmission of COVID-19 in children. The health problems in question include allergies and asthma, which are congenital diseases of children. Children with allergies or asthma will have a decreased immune defense response. Asthma in children results in a decrease in surfactants so that viruses that enter the lungs can easily infect and even cause other symptoms such as pneumonia in children (Ibrahim et al., 2020) In COVID-19, like other respiratory viruses, they can make their asthma symptoms worse and even have the potential to experience life-threatening asthma attacks. WHO also lists asthma as a condition that makes a person more susceptible to becoming more seriously ill due to the corona virus (Oreskovic et al.,2020). Based on the results of the review of the article, it can be stated that children who suffer from congenital diseases such as asthma and other chronic diseases are more at risk of being infected with COVID-19 but more specific examinations need to be carried out to ascertain whether the child is purely sick with the respiratory tract or is already infected with COVID-19.

\section{Nutrition Factor}

In the case of children with COVID-19 nutritional status was obtained in the research conducted (Hamadani et al., 2020) shows that nutritional status affects the transmission of COVID-19 in children. Poor nutritional status will result in decreased immunity of children so that the defense in the body decreases. This is in accordance with research by (Moradi et al., 2019) which states that children with good nutritional status have a lower risk of contracting viruses or bacteria than children with poor nutritional status. Adequacy of nutrition, especially vitamins and minerals, is essential in maintaining an optimal immune system. Vegetables and fruits are the best sources of various vitamins, minerals and fiber. Vitamins and minerals contained in vegetables and fruits act as antidotes to bad compounds or antioxidants in the body and help increase immunity. With increased immunity, it will prevent transmission of COVID-19. Nutrition is an important concern in maintaining the immune system. Fulfilled and good nutrition is needed for cells to function optimally. The activated immune system, in this case the higher the energy intake during the infection period, with the greater the basal energy expenditure (Moradi et al., 2019). Critically ill conditions in patients treated with COVID-19, require comprehensive management including nutritional therapy. Critically ill COVID-19 patients are under extreme stress, which places them at a high risk of malnutrition. Children have a low nutritional status because children have a tendency to consume only foods they like and prefer to eat only one type of food, so it is necessary to arrange food for children to meet the nutritional needs of children. The nutritional status of children is also determined by the socioeconomic status or income of the person, which results in the family's inability to provide nutritious food intake for their children In addition to the above factors, another host factor that is a risk factor for the transmission of COVID-19 in children is age, where the age of children under 5 years is more at risk of infection (Götzinger et al., 2020; Dong et al., 2020).

\section{Environment Factor}

\section{House Close Contact}

Indicates that the home is the most infectious site. Parents with no symptoms feel safe and ignore health protocols carrying the virus and interacting with the child. This interaction causes droplets that are scattered in the home environment and even directly on children, especially when not wearing masks. This is supported by the condition of the house that does not meet the criteria for a healthy home, so the virus will easily spread to all family members, not only children.

Close contact creates a direct relationship between 
children and parents. Parents who do not realize that they are carriers of the virus directly spread it through coughing or sneezing, the patient spreads the virus into the air in the form of droplet nuclei. One cough can produce about 3000 sparks. Generally transmission occurs in a room where sputum sparks last for a long time. Ventilation can reduce the number of splashes, while direct sunlight can kill viruses. Splashes can last for several hours in dark, humid conditions (Zhu et al., 2020). Family members including children who are close to sufferers of COVID-19 are the groups most vulnerable to contracting the COVID-19 disease because it is difficult to avoid contact with sufferers (Bellino et al., 2020). In fact, children are very difficult to separate from their parents. The interaction of children with parents is something that cannot be avoided. Children who miss their parents who work outside the home all day, and vice versa. This interaction includes holding the child, hugging and kissing the child. Some parents do not realize that they are a career that carries the virus everywhere, even in the home. We recommend that after work parents before meeting children clean themselves with a new shower and shampoo after changing to clean clothes to gather with children and other family members who are at home. So that it can reduce the cluster of transmission in the family.

\section{Children's Playground and School}

Lu et al., (2020) mentioned that the children's play environment and school are the most common places of transmission. Children who are carriers or carriers of the virus or confirmed with or without symptoms can leave the virus on inanimate objects in the environment around the child so that it is easily spread by the touch of other children or transmitted directly by sharing food or drinks in one container (Kannan et al., 2020). Not only that in research by Kursumovic et al., (2020) Viruses are often found in places that have been touched by sufferers such as door handles, chairs and tables so that children who often touch them can be infected indirectly from previous sufferers. The study in Singapore said there was widespread environmental pollution in rooms and toilets of patients experiencing mild symptoms of COVID-19. Virus can be detected on door handles, toilet seats, light switches, windows, cupboards and objects or devices that the patient may have touched but not found in air samples (Kannan et al., 2020). Based on the results of the study, it can be stated that often the children's play area has been contaminated from children who are positive for COVID-19 and / or parents who are positive for COVID-19 who accompany children who play. Based on the findings of the data, that children often share food in one container needs to be the attention of every parent. This often occurs in a child's play environment such as sharing drinking water and snacks with friends.

\section{Limitation}

A related limitation in this review is the potential for publication bias, because the included studies were those that the researcher could find, so that the minimal number of factors reviewed was limited to host and environmental factors, because there may be other factors that were not discovered and not examined by researchers and not found in the review, besides that the study was not conducted in all countries affected by COVID-19. More specific aspects related to policies to prevent transmission of COVID-19 in children need to be considered for implementing interventions in health facilities in each place.

\section{CONCLUSION}

Based on a review of the literature that was reviewed, it was found that the host factors that influence the incidence of COVID-19 in children are immunity, comorbidities, hygiene behavior or disobedience to health protocols and nutritional status. Children with low immunity and comorbid susceptibility to contracting the virus and will become severe when the child's nutritional status is poor. Meanwhile, the environmental factors of children tend to be transmitted at home and in the children's play environment. The existence of direct interaction between parents and children can make a cross-infection medium for children or interactions between children and playmates who are positive for COVID-19. To break the chain of the spread of COVID-19, it is hoped that every individual and society level implements the applicable health protocol, including for children. In addition, to adopt a healthy life, one should improve and maintain the immune system by improving balanced nutritional intake. So that you don't get infected with COVID-19 easily. Increase the intake of healthy and nutritious foods in the family, especially children, to increase immunity or immunity against viruses. The child's environment is an important thing to pay attention to because it is a medium for transmission of the COVID-19 disease that often occurs, so health education and personal hygiene behavior for children starting from parents, family, school, play 
environment, home environment, and especially social media educating children about health programs is necessary. The main type of education for school-age children who already understand can be taught about health protocols such as the correct use of masks, keeping a distance from fellow friends, learning how to wash hands properly, playing by avoiding crowds and reducing mobilization by studying and playing at home, now Many various kinds of children's toys teach children to be quiet in the house such as paper folding games, counting with various games, learning to sew with harmless materials and various interesting children's videos for children.

\section{Conflict of Interest}

The authors declare no conflict of interest.

\section{ACKNOWLEDGEMENT}

The authors are thankful to the institutional authority for completion of the work.

\section{REFERENCES}

Adhikari, S. P., Meng, S., Wu, Y. J., Mao, Y. P., Ye, R. X., Wang, Q. Z., \& Zhou, H. (2020). Epidemiology, Causes, Clinical Manifestation and Diagnosis, Prevention and Control of Coronavirus Disease (COVID-19) During the Early Outbreak Period: A Scoping Review. Infectious Diseases of Poverty, 9(1), 1-12.

Alligood, M. R., \& Tomey, A. M. (2014). Nursing theory and their work. The cv Mosby Company St. Louis. Toronto, Missouri.

Bellino, S., Punzo, O., Rota, M. C., Del Manso, M., Urdiales, A. M., Andrianou, X., \& Pezzotti, P. (2020). COVID-19 Disease Severity Risk Factors for Pediatric Patients in Italy. American Academic of Pediatrics, 146(4). https://doi.org/10.1542/peds.2020-009399

Cao, Q., Chen, Y. C., Chen, C. L., \& Chiu, C. H. (2020). SARS-CoV-2 Infection in Children: Transmission Dynamics and Clinical Characteristics. Journal of the Formosan Medical Association, 119(3), 670-673. https:/ /doi.org/ 10.1016/j.jfma.2020.02.009

De Luca, C. D., Esposito, E., Cristiani, L., Mancino, E., Nenna, R., Cortis, E., \& Midulla, F. (2020). Covid-19 in children: A brief overview after three months experience. Paediatric Respiratory Reviews, 35, 9-14.

Dong, Y., Mo, X. I., Hu, Y., Qi, X., Jiang, F., Jiang, Z., \& Tong, S. (2020). Epidemiological characteristics of 2143 pediatric patients with 2019 coronavirus disease in China. Pediatrics. https://doi.org/10.1542/peds.2020-0702

Duff, E. (2020). Global Health Emergency Declared By WHO. Midwifery, 83, 102668-102668. https://doi.org/https://doi.org/10.1016/j.midw.2020.102668

Götzinger, F., Santiago-García, B., Noguera-Julián, A., Lanaspa, M., Lancella, L., Carducci, F. I. C., ... \& Riordan, A. (2020). COVID-19 in children and adolescents in Europe: a multinational, multicentre cohort study. The Lancet Child \& Adolescent Health, 4(9), 653-661. https://doi.org/10.1016/S2352-4642(20)30177-2

Hamadani, J. D., Hasan, M. I., Baldi, A. J., Hossain, S. J., \& Shiraji, S. (2020). Articles Immediate impact of Stay-AtHome Orders to Control COVID-19 Transmission on Socioeconomic Conditions, Food Insecurity, Mental Health, and Intimate Partner Violence in Bangladeshi Women and their Families : An Interrupted Time Series. The Lancet Global Health, 8(11), 1380-1389. https://doi.org/10.1016/S2214-109X(20)30366-1

Hubiche, T., Phan, A., Leducq, S., Rapp, J., Fertitta, L., Aubert, H., ... \& Maruani, A. (2021). Acute acral eruptions in children during the COVID-19 pandemic: characteristics of 103 children and their family clusters. In Annales de Dermatologie et de Venereologie (Vol. 148, No. 2, pp. 94-100). Elsevier Masson. https://doi.org/10.1016/j. annder.2020.11.005

Ibrahim, L. F., Tosif, S., McNab, S., Hall, S., Lee, H. J., Lewena, S., \& Babl, F. E. (2020). SARS-CoV-2 Testing and Outcomes in the First 30 days after the First Case of COVID-19 at an Australian Children's Hospital. EMA Emergency Medicine Australasia, 32(5), 801-808. https://doi.org/10.1111/1742-6723.13550 
Kannan, S., Shaik Syed Ali, P., Sheeza, A., \& Hemalatha, K. (2020). COVID-19 (Novel Coronavirus 2019) - Recent Trends. European Review for Medical and Pharmacological Sciences, 24(4), 2006-2011. https://doi.org/ 10.26355/eurrev_202002_20378

Kobayashi, T., Jung, S., Linton, N. M., Kinoshita, R., Hayashi, K., Miyama, T., \& Nishiura, H. (2020). Communicating the Risk of Death from Novel Coronavirus Disease (COVID-19). Journal of Clinical Medicine, 9(2), 580. https://doi.org/10.3390/jcm9020580

Kursumovic, E. (2020). Deaths in Healthcare Workers due to COVID-19 : The Need for Robust Data and Analysis, Anaesthesia, 989-992. https://doi.org/10.1111/anae.15116

Le, H. T., Nguyen, L. V, Tran, D. M., Do, H. T., Tran, H. T., Le, Y. T., \& Phan, P. H. (2020). Case Report the First Infant Case of COVID-19 Acquired From A Secondary Transmission in Vietnam. The Lancet Child and Adolescent Health, 4(5), 405-406. https://doi.org/10.1016/S2352-4642(20)30091-2

Liu, T., Liang, W., Zhong, H., He, J., \& Chen, Z. (2020). Risk Factors Associated with COVID-19 Infection: A Retrospective Cohort Study Based on Contacts Tracing. Emerging Microbes \& Infections, 9(1), 1546-1553. https://doi.org/10.1080/22221751.2020.1787799

Liu, Y., Gu, Z., Xia, S., Shi, B., Zhou, X. N., Shi, Y., \& Liu, J. (2020). What are the Underlying Transmission Patterns of COVID-19 Outbreak? An Age-Specific Social Contact Characterization. Eclinical Medicine, 22, 100354. https://doi.org/10.1016/j.eclinm.2020.100354

Ludvigsson, J. F. (2020). Systematic Review of COVID-19 in Children Shows Milder Cases and a Better Prognosis than Adults. Acta Paediatrica, 109(6), 1088-1095.

Manderson, L., \& Levine, S. (2020). COVID-19, Risk, Fear, and Fall-out. Medical Anthropology, 39(5), 367-370. https://doi.org/10.1080/01459740.2020.1746301

Moradi, S., Mirzababaei, A., Mohammadi, H., Moosavian, S. P., Arab, A., Jannat, B., \& Mirzaei, K. (2019). Food Insecurity and the Risk of Undernutrition Complications Among Children and Adolescents: A Systematic Review and Meta-Analysis. Nutrition, 62, 52-60.https://doi.org/10.1016/j.jaip.2020.05.027

Oreskovic, N. M., Kinane, T. B., Aryee, E., Kuhlthau, K. A., \& Perrin, J. M. (2020). The Unexpected Risks of COVID19 on Asthma Control in Children. The Journal of Allergy and Clinical Immunology: In Practice, 8(8), 2489-2491. https://doi.org/10.1016/j.jaip.2020.05.027

Saha, J., \& Chouhan, P. (2020). Indoor air pollution (IAP) and pre-existing morbidities among under-5 children in India: are risk factors of coronavirus disease (COVID-19)?. Environmental Pollution, 266, 115250.

Sun, K., Chen, J., \& Viboud, C. (2020). Early Epidemiological Analysis of the Coronavirus Disease 2019 Outbreak Based on Crowdsourced Data: A Population-Level Observational Study. The Lancet Digital Health, 2(4), 201-208. https://doi.org/10.1016/S2589-7500(20)30026-1

Wang, C., Pan, R., Wan, X., Tan, Y., Xu, L., Ho, C. S., \& Ho, R. C. (2020). Immediate Psychological Responses and Associated Factors During the Initial Stage of the 2019 Coronavirus Disease (COVID-19) Epidemic Among The General Population In China. International Journal of Environmental Research and Public Health, 17(5), 1729. https://doi.org/10.3390/ijerph17051729

Wu, Q., Xing, Y., Shi, L., Li, W., Gao, Y., Pan, S., ... \& Xing, Q. (2020). Coinfection and other clinical characteristics of COVID-19 in children. Pediatrics, 146(1).

Wilke, N. G., Howard, A. H., \& Goldman, P. (2020). Rapid Return of Children in Residential Care to Family as a Result of COVID-19: Scope, challenges, and recommendations. Child Abuse and Neglect, 110(2), 104712. https://doi.org/10.1016/j.chiabu.2020.104712 
Ying, Y., Ruan, L., Kong, F., Zhu, B., Ji, Y., \& Lou, Z. (2020). Mental Health Status among Family Members of Health Care Workers in Ningbo, China, During the Coronavirus Disease 2019 (COVID-19) Outbreak: A Cross-Sectional Study. BMC Psychiatry, 20(1), 1-10. https://doi.org/10.1101/2020.03.13.20033290

Yuliarto, H. (2008). Latihan Fisik dan Kekebalan Tubuh. Medikora, (1).

Zar, H. J., Dawa, J., Fischer, G. B., \& Castro-Rodriguez, J. A. (2020). Challenges of COVID-19 in Children in Low-and Middle-Income Countries. Paediatric Respiratory Reviews, 35, 70-74. https://doi.org/10.1016/j.prrv.2020.06.016

Zhou, M., Xie, X., Peng, Y., Wu, M., Deng, X., Wu, Y., \& Shang, L. (2020). From SARS to COVID-19 : What we have Learned About Children Infected with COVID-19. International Journal of Infectious Diseases, 96, 710-714. https://doi.org/10.1016/j.ijid.2020.04.090

Zhu, W., Wang, J., He, X., Qin, Y., Yang, S., Hu, X., \& Zhou, S. (2020). The Differential Diagnosis of Pulmonary Infiltrates in Cancer Patients During the Outbreak of the 2019 Novel Coronavirus Disease. Zhonghua Zhong Liu Za Zhi, 42(4), 305-311. 